\title{
Sasak Elite Development In Identity Construction In The Global Era In East Lombok, Nusa Tenggara Barat Propince
}

\author{
A.A. Ngurah Anom Kumbara ${ }^{1 *}$, A.A. Sagung Kartika Dewi ${ }^{2}$ \\ Department of Anthropology, Faculty of Culture Science, Udayana University, Denpasar, \\ Indonesia $^{1}$ \\ Department of Management, Faculty of Economic and Business, Udayana University, \\ Denpasar, Indonesia ${ }^{2}$ \\ \{anom_kumbara@unud.ac.id ${ }^{1}$, sagung_kartika@unud.ac.id ${ }^{2}$ \}
}

\begin{abstract}
Globalization and the enactment of Law No. 34 of 2003 concerning regional autonomy after national political reform got a positive response from ethnic groups in the Unitary Republic of Indonesia (NKRI). This condition was then used as a momentum to fight for and construct the identity of the group. The specific objectives of this study were: 1) to understand the strategies developed by the Sasak elite in constructing identities, and 2) to analyze elite struggles in articulating their identities to meet various interests. The method of data collection is done by observation, interviews, and documentation. Data analysis was conducted qualitatively- interpretatively using the triangulation model, namely data reduction, data expose, and verification. The theoretical basis used to analyze research problems is critical theories, namely power relations, hegemony, and social practice. Based on the data analysis, this study concluded that the strategy developed by the Sasak elite in constructing the identity and at the same time maintaining its privilege authority was to use capital, religion, custom and ethnicity as instruments. The form of elite struggle in articulating the Sasak identity is to fuse the values of religion, customs, and modernity as a unit whose existence is not contradicted.
\end{abstract}

Keywords: articulation; elite sasak, strategy; capital

\section{Introduction}

Globalization and the enactment of Law No. 23 of 2003 concerning Regional Autonomy after political reform has made important momentum by ethnic groups in Indonesia to construct their identities, so that the political movement for identity has become more prominent lately. One of them is done by Sasak ethnic in Lombok Island. Identity political movements carried out by the Sasak ethnic group are assumed to have a dual purpose, on the one hand it is an instrument to increase solidarity between them in an effort to seize the domination of other ethnic groups, both in the political, economic and cultural fields. On the other hand, it is to counteract the swift flow of secular capitalism that has plagued Sasak 
people in the past two decades. The formulation of the local identity of the Sasak tribe is assumed by them to have existed in the collective ideas of the Sasak people. Collective ideas in the form of wisdom cultural values and symbols embodied in the Sasak tradition are reformulated to be used as a shield to counter the negative effects of globalization. Such a movement could theoretically view is part of the political process of Sasak identity in responding to changes and challenges faced (Avonius, 2004, Barker, 2004). In addition, these actions can also be interpreted as a form of expression of Sasak ethnic group resistance to the objective conditions they face, both geo-political, sociological, economic, and historical (Sihbudi \& Nurhasim, 2001). Based on this background, the objectives of this study are 1) to understand the elite strategy of Sasak in constructing identity in the global era in East Lombok; 2) to analyze the struggle of the Sasak elite in articulating identity in the global era.

\section{Concept and Theory}

\subsection{Politics of Identity}

Social science and humanities studies on identity politics show that ethnic or cultural identity is deliberately constructed (Berger, 1973; Giddens, 1991; Hall, 1992; Eriksen, 2004). However, among them there are still disagreements about how far the construction of cultural identity with the historical experiences of a particular ethnic group. According to Mead, social identity is a social conception of self in which the individual will live his self ... "from the point of view of the social group as a whole", where it originates (Kuper \& Kuper, 2000: 986).

Eriksen (2004: 156), formulating social identity is ... "social identification has to do with which groups a person belongs to, who, he or she identities with, how people establish and maintain invisible but socially effects boundaries between us and them". Identity is entirely a social construction and cannot exist outside of cultural representation and acculturation (Barker, 2000: 170). Identity projects build what we think about ourselves today from the point of the past and present situation together with what is thought and desired in the path of hope for the future. Identity is an essence that can be interpreted through signs of taste, beliefs, attitudes, and lifestyle. Identity is considered both personal and social and indicates that "we are the same or different" from others (the others). When the signs are attached to certain ethnic groups, they are called ethnic identities. Thus, identity in this context is understood not as a permanent entity, but something that is created, something that is always in the process, a movement ahead of something that comes later, and as a description of ourselves that is filled emotionally in the context of a particular situation.

The search for the meaning of identity is an endless because identity is not a final, static, and successful entity, but something that grows and develops. Stuart Hall (1990) called it "something that is never perfect", always in the process and always built from within. The word identity itself is a key word that can refer to any connotation, such as social, political, cultural, and so on. Identity for certain situations can mean worry, fear of self. This occurs when the terminology of identity is in a defensive position. In the situation of globalization, for example, a political movement for national identity, ethnic or religious identity emerged as a trend in Indonesia. Thus, it can be understood that self-identification based on social reality, such as religion, customs, language, and ethnicity together can form ethnicity or be label ethnicity. Various conflicts between ethnic groups, especially in the "minority and majority" groups are usually based on claims regarding recognition of prestige, group identity, population rights, political power, and access to economic opportunities. 


\subsection{Elite and Discourse on Power}

Elite. In the study of the elite there are at least two important perspectives that can be referenced, the first from the pluralist perspective, the second from the Marxian perspective. Pluralists such as Laswell, and Dahl, consider that in every society important decision in the society concerned are often made by a small group of people called the elite. In the view of Laswell and Dahl (Maliki, 2004), the elite is identified as a small group of people who own and get more than what most people have and get. Pareto mention, that those who have and get more than others, there are those who hold power or governing elite and there are those who do not hold power or non-governing elites (Maliki, 2004: 14). Power is the ability of a person or group of people to impose their desires on others even with the power of an antidote, either in the form of a permanent reduction of the rewards provided, or in the form of punishment. Both are considered equally negative. The ability to produce influence through power has given him a way to use negative sanctions.

\subsection{Discourse of Power.}

According to Michel Foucault (1980) discourse is understood as an explanation, definition, classification, and thinking about people, knowledge, and abstract systems of thought - all of which are inseparable from power relations. Further it is said that discourse means talking about rules and practices that produce meaningful statements in a certain historical range. Discourse also means a regulatory mechanism that works very neatly, which involves discipline, institutions, and professionalism. Discourse is a social law that sets rules about acceptable ways to discuss, define, writes and act around certain topics. So, the discourse is a narrative, where the mode of conversation, definition, writing, and practice outside the scope of the dominant discourse, is interpreted as an act of betrayal.

Foucault, (1980; 2012), explain power is a fundamental and inevitable social life dimension. Power is not property, but strategy. Power is a matter of practice that occurs within a certain scope-where in that scope there are many strategic positions that are related to one another and are constantly shifting. Strategy takes place everywhere. Power does not come from outside (external), but determines the structure, rules, and relationships from within; and allows all that to happen. Power is always intertwined with knowledge, expressing one another to another - there is no power relation without being stated in the relationship of the knowledge area --- the knowing subject, and the known object. Power is always articulated through knowledge production so knowledge must have effect on power. It is almost impossible to gain power without being supported by knowledge and economics as the basis of its administration. Power does not always work through oppression and repression, but often through normalization and consensus. Power and produces of knowledge, especially science provides power. Power is spread; is everywhere, not all-encompassing power, but power comes from everywhere. Thus, Foucault's thought is different from Marx's, which sees and understands power only in the state, which is the main ideology of Marxism.

Referring to the theorization explanation is associated with the tendency of phenomena that develop in Lombok island, the perspective is used as a basis for understanding the motives of the Sasak Islamic elite, indigenous Sasak elite, and modern Sasak elite in the process of constructing Sasak identity in relation, both with roles its structural and functional, power, and the interests of certain agencies more broadly. 


\section{Research Methods}

This research was designed using a qualitative approach. Data collection techniques are done by observation, in-depth interviews, Focus Group Discussion (FGD) and documentation. The main research subjects are religious elites, Indigenous elites, and modern elites (bureaucracy) who live in East Lombok. The technique of determining informants is done in two ways, namely snowball and purposive. When the study was conducted for 3 months, from July to September 2019.

\section{Results and Discussion}

\subsection{Strategies of Sasak Islamic Elite (Tuan Guru) in Identity Construction}

To realize the ideals of establishing an ideal Sasak identity and at the same time to preserve the privileges and status quo they have, the Sasak Islamic elite or Tuan Guru, the indigenous Sasak elite, and the modern Sasak elite in East Lombok have taken various strategic steps and strategies. Empirically there are variations in models and strategic paths undertaken by the Sasak elite to achieve these goals, namely the path of education, politics, and ritual traditions.

The education route was carried out by establishing Islamic-based schools from the elementary school level to the tertiary or university level. In this pathway, through Islamic organizations especially Nadatul Watan, which was founded by Mr. Zainuddin Abdul Majid, succeeded in establishing the Sasak identity as adherents of Islam who practice their teachings according to the Alquran and Hadith. In addition, the Tuan Guru also intensively taught Islamic teachings in his Islamic boarding schools, which spread throughout the Lombok region. The political path was carried out by going directly into the arena of practical politics to win positions in the legislative and executive branches, especially in the post-reform era. This effort was achieved because they realized the potential of their voters very much, which in the period before the reform of their political potential was used by the political elite, especially from the Golkar party. While the ceremonial ritual path was carried out by doing sermons around in Islamic boarding schools especially in East Lombok, on Islamic holidays, such as Idul Fitri, Idul Hadda, and Muharam. In summary, the paths field and forms of strategy carried out by religious elites in constructing Sasak identities are as follows.

\subsection{Indigenous or Traditional Sasak Elite Strategy}

The main force of the survival of the authority and influence of the traditional aristocratic or elite Sasak tradition in the social stratification system in Lombok, is highly depend upon the survival of the customs that supports the stratification system. Conversely, if custom as a supporter of the stratification system is no longer recognized or abandoned by the community, then the significance of their influence and privilege authority will fade. Sasak aristocrats have concerns about this and are very aware of the potential for change. On that basis the indigenous elites use tradition as a shield of self-defence and at the same time as a sign of the existence of their identity. In addition, the reproduction of discourse about the need for Sasak people to preserve wisdom cultural values and traditional organizations of ancestral heritage such as hamlets, banjar, Sasak Indigenous Organization (MAS), and art galleries are used as sources of power legitimacy. These forms of strategy include the organization of the Sasak's create Culture Appreciation Month, namely the promotion and preservation of Sasak customs, 
art and local culture in the form of dissemination of translations of ancient texts containing the wisdom of Sasak's culture. Also sponsoring seminars on the potential of local culture for Sasak development, holding a Sasak traditional fashion contest and arts which are considered Sasak distinctive, namely Gendang Beleq music and Presean art.

\subsection{Modern Sasak Elite Strategy (Bureaucratic Elite Strategy)}

The political elites who froze in East Lombok after the reformation mostly still come from aristocratic family groups and families of modern-educated clerics or at least are families known by the community as families with strong religious traditions, but have an orientation to build a modern Sasak identity. Therefore, it can be assumed that the reproduction and manipulation of symbols originating from Islam, local traditions, and the value of modernity will be used as important political resources to gain public support in efforts to build a shared identity and at the same time maintain the hegemony of its power. The form of the strategy is carried out with the activities of fostering Sasak arts and culture, cooperation with Islamicbased political parties to build mosques and giving alms to the poor, as well the coronation of himself as the descendant of King Seleparang to revive the historical memory of the glory of the Sasak Kingdom which was thought to have existed before the invasion of Raja-Bali's power.

The description of the phenomenon identified that the strategies and efforts of the Sasak elite to build and maintain their identity, charisma, legitimacy of the status quo were not from one way, but from many sources. Weber (in Ritzer, 2004) mentions three sources of legitimacy, including through preservation: (a) charisma, (b) the accumulation of traditional symbolic sources, and (c) rational legal sources. With these three sources, as carried out by the Sasak elite in Lombok, they were able to construct their identities once they could maintain their power over the people without resorting to violence. Thus, symbolic, cultural, and economic capital (Bourdieu, 1991), by the Sasak elite, has been exchanged, which in turn is creatively and contextually used as an instrument, in addition to the interests of collective identity as well as the interests of elite power itself.

\subsection{Transform Articulation of Sasak Identity: Adatluwirgama}

In this decade, the tendency of controversy, contestation, and antagonism of tradition, Islamic and modern discourse on Lombok Island has decreased significantly. On the contrary, the appreciation and efforts of Sasak people to mix and construct an order of socio-cultural values based on Islam, traditions, and modern cultural values to be used as symbols of their identities are even more prominent. The ideal form of social and cultural order that will be built in the public discourse that developed in East Lombok in these two decades is the Adatluwirgama discourse. In the Sasak elite discourse, Adatluwirgama as a valuable cultural system, contains three basic principles as a pattern for the action of Sasak people in Lombok, namely knowledge systems or cognition systems, value systems, and symbolic systems. The three forms of culture have their respective functions interactively, namely the knowledge system functions as a source of information and motivation, the value system functions evaluatively, and the symbol system functions as a means of communication and integration for the life and existence of the Sasak people. Symbolic forms of the cultural system which are considered to hold various meanings, are often used as a blueprint for the action of Sasak people in interacting with their social and cultural environment. With this collection of meanings, both individual and collective of the Sasak tribe interprets his experience and regulates his actions. 
The Sasak cultural system as a source of information and motivation which has the broadest scope and universal value for Sasak people in their interactions with nature, God, and fellow members of society is "Aqidah and Islamic Sharia". In the human dimension, the Islamic ideology by the Sasak elite is held to contain universal values that can guarantee peace and respect differences in the expressions of certain cultural adherents or appreciate the local traditions embraced by the community where Islam exists as seen in the last statement of Rupina (56 years old), from the modern elite, namely: "there is no fundamental difference between tradition values (customs) and Islam, but instead glorifies religion; likewise the values of modernity need to be adopted and developed because we need to progress the Sasak people going forward ". So, if there are different things that need not be disputed let alone have to negate one another "(interview, July,2019). Thus, the discourse of Adatluwirgama as a form of accommodative articulation of philosophical values originating from Islamic creed and Sharia and practical humanitarian values originating from local traditions are used as constructions of Sasak's ideal cultural identity which are sourced, considered to be a representation of a fusion between Islamic, local tradition, and modernity values.

\section{Conclusions}

The forms of strategies developed by the Sasak Islamic elite, the Sasak indigenous elite, and the modern Sasak elite to preserve their identity appear to be very diverse, but there is a tendency for these elites to use and manipulate the religious, customary and ethnicity symbols as modalities the main power, both in informal tradition and formal bureaucratic. The form of Sasak ideal identity articulation that would be used as their collective identity is "cultural identity" which reflects the fusion between the knowledge system, value system, and symbol system contained in the Sasak tradition with Islamic values, and modern elements in public discourse, in locally called Adatluwirgama. This identity construction is expected, besides being able encoring certain practical functions, it can also be used as a pattern for and patterns of action in social life that are in accordance with the character of Islamic Sasak's.

\section{Acknowledgment}

The writer expresses his gratitude to the Chancellor and Chairperson of the University LPPM for the financial assistance and facilities provided to us so that this research can be carried out. We would also like to thank the informants, the research team, and others who have helped so that this research can be completed on time.

\section{References}

[1] Agger, Ben. 1992. Cultural studies as Cultural Theory. London: Falmer Press.

[2] Avonius, Leena, 2004, Reforming Wetu Telu: Islam,Adat,and the Promises of Regionalism in Post New Order Lombok. Liopistopaino,Helsinki.

[3] Barker Chris,2004. Culture Studies Teori dan Praktek. (Terjemahan). Yogyakarta: Kreasi Wacana. 
[4] Bartholomew, R. John, 2001, Alif Lam Mim Kearifan Masyarakat Sasak, Yogyakarta: Tiara Wacana.

[5] Berger, Peter L., dan Thomas Luckmann,1973, The Social Construction of Reality: A Treatise in the Sociology of Knowledge, Garden City New York: Acor.

[6] Bourdieu, Pierre,1991, Language and Symbolic Power. Cambridge, Massachusetts: Harvard University Press.

[7] Budiwanti, Erni,2000, Islam Sasak Waktu Telu versus Waktu Lima, Yogyakarta: LkiS.

[8] Cederroth, Sven, 981. The Spell of The Ancestors and The Power of Mekkah: A Sasak Community on Lombok. Sweden: Acta Universitatis Goyhoburgensis.

[9] Eriksen, 1993. Ethnicity \& Nationalism: Anthropological Perspective, London and Boulder, Colorado: Pluto Press.

[10] Foucault, Michel,1980. Power Knowledge. Cambridge University Press

[11]Foucault, Michel, 2012. Arkeologi Pengetahuan. (Tenerjemah). Yogyakarta: IRCiSoD

[12] Giddens, Anthony, 1991, Modernity and Self-Identity: Self and Society in the late Modern Age. Stanford: Stanford University Press.

[13] Hall Stuart,1990. Cultural Identity and Diaspora". In J. Rutherford (ed). Identity, Community, Culture and Difference. London: Lawrence \& Wishart.

[14]Kuper and Kuper,2000. Ensiklopedi Ilmu-Ilmu Sosial. Jakarta: PT Raja-Grafindi Persada.

[15]Lombok Dalam Angka, 2015. Bappeda Propinsi NTB, 2015.

[16] Maliki, Zainuddin,2004. Agama Priyayi. Yogyakarta: Pustaka Marwa.

[17] Ritzer, G.,Goodman, J.D.,(eds) 2004. Teori Sosiologi Modern. (Terjemahan), Jakarta: Prenada Media

[18] Sihbudi, R., Nurhasim, M.,1984. Kerusuhan Sosial di Indonesia, Studi Kasus Kupang, Mataram dan Sambas. Jakarta: PT Grasindo. 